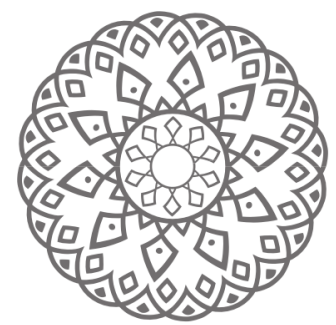

\title{
IsLAMIC LAW AND WOMEN'S RightS IN INDONESIA: A Case of Regional Sharia Legislation
}

\author{
Nur Hidayah
}

\begin{abstract}
Abstrak: Kebijakan desentralisasi memberi banyak wewenang untuk mengelola urusan lokal daerah sendiri. Beberapa provinsi dan kabupaten yang mayoritas Muslim telah mengeluarkan peraturan daerah (Perda) syariah berdasarkan aspirasi rakyat dan kekhasan lokal. Fenomena ini telah menimbulkan pertanyaan apakah otonomi daerah akan membuka peluang baru bagi perempuan untuk mempromosikan hak-hak mereka di daerahnya sendiri atau akan menghambat kemajuannya. Untuk menjawab pertanyaan semacam itu, penelitian ini pertamatama akan membahas kebijakan desentralisasi yang membuka peluang bagi legislasi syariah regional. Kemudian, pemeriksaan substansi hukum apa yang disebut perda syariah tersebut dan dampaknya terhadap hak-hak perempuan. Temuan penelitian ini memperlihatkan adanya pengaruh interpretasi syariah konservatif yang sarat dengan nilai-nilai patriarki sehingga peraturan berbasis syariah ini mendiskriminasi perempuan, sebagaimana tercermin dalam ketentuan mereka mengenai peran keluarga dan sosial perempuan, aturan berpakaian, jam malam, segregasi publik, dan prostitusi. Munculnya konservatisme Islam selama demokratisasi Indonesia dan kurangnya perspektif gender dalam kebijakan desentralisasi baik di tingkat pemerintah daerah dan masyarakat telah berkontribusi terhadap undang-undang syariah regional yang diskriminatif ini. Oleh karena itu, ada kebutuhan mendesak untuk mereformasi interpretasi agama yang konservatif serta kebijakan jender yang lebih sensitif dalam menerapkan desentralisasi sehingga syariah dan otonomi daerah dapat berjalan beriringan untuk bersama-sama mendukung penguatan hak-hak perempuan.
\end{abstract}

Kata kunci: Hukum Islam; Desentralisasi; Perda Syariah; Hak-Hak Perempuan 
Abstract: Under Indonesia decentralization policy which grants regional governments more authority to manage their own local affairs, some predominantly Muslim regions have passed sharia regional legislation on the ground of popular aspirations and local particularities. It has raised a question of whether the regional autonomy will provide new opportunities for women to promote their rights within closer local governments or it will inadvertently restrain women's advancement. Answering the question, this paper will firstly discuss the decentralization policy that opens up the opportunity for regional sharia legislation. Then it will examine the legal substance of the so-called perda (sharia-based bylaws) and their impacts on women's rights. Being influenced by conservative sharia interpretation laden with patriarchal values, these shariabased bylaws discriminate against women, as reflected in their stipulations regarding women's familial and social roles, dress codes, curfews, public segregation, and prostitution. The rise of Islamic conservatism during Indonesian democratization and the lack of gender perspectives in the decentralization policies have contributed to such discriminatory regional sharia legislation. Therefore there is an urgent need for religious reform as well as more sensitive gender policies in implementing the decentralization so that the sharia and regional autonomy can go hand in hand to support women's rights promotion.

Keywords: Islamic Law, Decentralization, Sharia Regional Legislation, Women's Rights 


\section{Introduction}

On 27 February 2006 in Tangerang municipality, Banten, Lilis Lindawati, a wife of a primary school teacher in Tangerang, was arrested by local police, when she was waiting for transportation to go home from work. On that night she and other 10 innocent women were arrested under a charge of being prostitutes. The next day, without a lawyer, and before a crowd of local people, she faced a trial. Based on a fact that she was out at night and her make-up arouses suspicion that she is a prostitute, Lilis was found guilty to infringe the Tangerang by laws No. 8/2005 on Anti- Prostitution. Unable to pay the fine of around $\mathrm{A} \$ 50$, she spent the next three nights in prison (The Age, http:// news.sbs.com.au/dateline/index.php?page $=$ transcript $\&$ d te $=2006-$ 06-28\&headlineid=1139 [retrieved at 30 September 2007). Similar cases, such as jilbab (veil) raids, women domestication and gender segregation, are experienced by women in other regions whose regional governments have implemented regional sharia legislation.

Since the implementation of Law No. 22/1999 on regional autonomy in 2001, approximately 93 edicts, decrees, or bylaws related to sharia moral codes have been issued by regional governments (Bush, 2007). Although these bylaws do not clearly use the word sharia as the title, the drafters and promoters regard them as sharia (White, 2006). Previous studies on Islamization of law in some other Muslim countries reveal that conservative sharia interpretations adopted in such a program have led women to suffer from many disadvantages (Mayer, $1990,: 13-52$ ). This raises a similar question of how shariatisation in Indonesian regional autonomy era influence women's rights. To answer the question, this paper firstly will discuss the decentralization policy that has opened up the possibility for the sharia regional legislation. Next it seeks to analyze the legal substance of these bylaws and their impact on women's rights. Afterwards it will analyze the socio-political factors of this regional sharia legislation that tend to discriminate women and in light of this, some possible solutions will be recommended.

\section{Decentralization and the Sharia Regional Legislation}

Literature on women and local government mainly points out that decentralization will provide more space and opportunities for women to represent their needs and interests as it brings politics closer 
and more accessible to women (Philips, 1998). This argument lies on the assumption of the relevance of local government's functions with women's roles and needs that will encourage women to engage in politics at the local level or to concern themselves with the kinds of decision that are made in their local environment. Thus, decentralization could help shift the balance not only between central and local government but also between men and women (Philips : 111). Macaulay argues that "the local arena is a hybrid one, poised between community and the state, private and public, the household and town hall, and thus offers a cross-over space for women" (Macaulay : 105).

However, locality could also pose a challenge to women. Local elites and communities tend to be resistant towards changes. Phillips argues that homogeneity in local communities contributes to such communities' intolerance toward people who want to challenge their current conditions (Philips : 120). Any changes brought by national government and international bodies often face resistance from local communities especially if such changes might undermine traditional norms and structure that have served their interests for a long time. In the context of gender issue, such locality might impede the attempt to revert pattern of women's subordination at the local level (Byme and Laier, : 35).

According to Abidin, decentralization in Indonesia has not so far increased women's participation in public decision making (Abidin, http://www.policy.hu/siahaan/researchpaper3.htm, retrieved at 13 September 2007, p.21). Although women representation at the local level is increasing during regional autonomy era, the figure is relatively still low (Ibid, 2006). In terms of institutions, under the decentralization policy, focal points for women empowerment have been established in 30 provinces. However, not all district and municipalities have women's empowerment bureaus. The existing focal points also face huge problems such as limited fund, competitions with other sections in local government offices, and the lack of political will among local governments to promote gender equity (Ibid, 2006). This is partly attributable to law No. 22/1999 on regional autonomy that lacks a gender perspective as there is no provision in this law stipulating its importance in local government. The law focuses on strengthening local government and local legislative 
without mentioning mechanism for increasing women representation and participation in local politics.

The lack of gender perspective is not only reflected in the regulation on local government but also in the one on community participation. Article 104 on community participation that allows the revitalization of customary institutions is not accompanied by a regulation to prevent the revival of patriarchal values embedded in many of these customary institutions (Noerdin, 2002 : 182).

The case of the revitalization of Nagari system in the Minangkabau ethnic group in West Sumatra might well illustrate this point. Although the society is traditionally organized along matrilineal lines, it does not necessarily guarantee women's participation in decision-making because the authority for decision-making and inheritance guardianship is in fact handed over to the ninik-mamak (male elders). So the restoration of Nagari system implies the deprivation of Minangkabau women from their communal rights (Ibid).

In certain regions with Muslim majority populations, the revitalization of customary institutions is often linked with demands for the implementation of sharia (Islamic law). Being suppressed by the Soeharto regime under his policy to homogenize the country, both Islam and customary institutions now find a channel to revive. Some previous studies on regional sharia legislation point out that the appeal for such sharia implementation has been actively propagated by conservative Muslim groups, such as PKS (Partai Keadilan Sejahtera/ Prosperous Justice Party), HTI (Hizbut Tahrir Indonesia/Indonesian Salvation Front), MMI (Majelis Mujahidin Indonesia/Indonesian Mujahidin Forum), DDII (Dewan Dakwah Islam Indonesia/the Indonesian Council for Islamic Predication), DI (Darul Islam/the House of Islam) and FPI (Front Pembela Islam/Islamic Defenders Front) in collaboration with local elites and governments (Wieringa, 2006) only Muslims over non-Muslims but also male over female (AnNa'im, , $2005: 61$ ). Being patriarchal in nature, the revitalization of both customary and sharia values has resulted in negative impacts on women. Both tend to treat women as merely the object of law and even worse the symbol of culture and Islam. 


\section{Women under the Sharia Regional Legislation}

To assess the influence of shariatisation on women's rights, this section will examine the legal substance of sharia based-bylaws in some Muslim provinces or districts by comparing them with the both conservative and progressive interpretations of sharia and also assess the impacts of such stipulations on women's rights. For the purpose of analyses, the provisions might be categorized into five themes:

\section{Women's Familial Roles}

The stereotype of a Muslim woman whose primary role is as a wife and a mother is still adopted in most Sharia-based bylaws. For example, the Guideline of Movement of Good-Attitude Bureaucrats and Merciful Society (Gerbang Marhamah) based on Cianjur Regional Head's Circular Letter No. 451/2719/ASSDA lays down a guideline for building peaceful families emphasizing the character building of obedient wives and dutiful mother in accordance with the stereotype. This perspective is based on the conservative sharia interpretation on gender roles that stipulates women's priority responsibilities as caregivers, nurtures, and service providers for the needs of her male family members. In a more benign form of this perspective, a woman is allowed to take part in other social activities such as having a career outside the home, however, this must be under the permission of her husband (Othman, $2006: 342$ ).

This perspective, based on literal interpretation of QS 4: 34, lies on an assumption that female is secondary to her male counterpart because of male's guardianship over female as reflected in male's obligation to provide the marriage dowry and maintenace as well as to protect her life, morality and chastity. As a reverse, a Muslim wife must be obedient and must not commit nushuz (rebellion of the wife against her Muslim husband's authority) (Memissi, 1996 : 109-120). To indicate her obedience, a wife is demanded to have marital fidelity, friendly behavior toward the husband and his family, and good household management. Furthermore, in this perspective, a husbands' authority over his wife also includes the right to discipline her if she is disobedient. The measures are gradual from lenient to harsh one based on the degree of the wife's disobedience: from admonishment to bed separation until wife battery if she persists to be disobedient (Stowasser, 1998 : 33). 
In this perspective, women have only little control over their lives and they are even deprived of their rights for self-determination. The domestication of women based on this perspective will, of course, further limit their freedom. Mayer points out that “... [I]n so far as the application of Islamic criteria means that Muslim women are confined in the home and excluded from situations where they will have contact with men, they will also be indirectly denied many other freedoms as well" (Mayer, 1991 : 124). According to Fish, there is a relationship between patriarchal culture of Muslim societies that subordinates Muslim women and the nature of authoritarianism of such societies which further impedes their advancement. He asserts that women's subordination in Muslim societies may influence life not only in the family and immediate community but also at higher levels, because gender inequalities in social relations may reproduce themselves in state politics (Fish, $2002: 25-30$ ). In a similar vein, Sharabi contends that a culture of domination, intolerance, and dependency in social and political life might reflect the repressiveness and unquestioned dominance of the father in the family and of the man in relations between men and women (Sharabi, 1988 : 32-39). Fish further asserts that when oppression has become a habit of life not only in private but also in public spheres, people tend to take authoritarianism for granted. This then will block the freedom and advancement of such a society (Fish, 2002 : 25-30). Therefore contemporary progressive Muslim scholars have countered such conservative interpretation of QS 4: 34 by either looking it from historical perspective and/or emphasizing more on spirit of gender equality in the Qur'an (Stowasser, : 38-42).

\section{Women's Social Role}

The pattern of gender relation between men and women in the family influences the capabilities of women to take part in and to benefit from social political life. Within such a stereotype, a Muslim woman tends to be preoccupied with private works, thus, does not have, or at least has only limited, time to participate in community forums or other public activities in which decision making takes place. In such a society women will be invisible which further implies their needs and interest will not even be taken into considerations in decision making, thus, they are treated only as object of policies. 
Even when women are allowed to take part in public sphere, the responsibility of taking care of the household and family are still on women's hands and men are likely to be reluctant to share these private works. Her activities in private spheres have never been counted and paid as productive works in public domain. Thus, working women have to bear double burdens in their life. These double burdens are sometimes further complicated by discriminative treatments that women get in work place. Working women are usually not considered as primary breadwinners, thus, women are usually paid less than men. A study on the impact of women's sex stereotyping stipulated in the National Marriage Law that treats a woman as a wife and a mother reveals that such a stereotype influences the perpetuation of discriminative measures against women as reflected in: 1)1. The policy of banning factory female workers to work at night; 2) 2. Wage discrimination because women are not considered as primary breadwinners (Circular Letter from the Minister of Labor Force No. 4/1998); 3) 3. Tax file number of a wife follows the one of her husband (Decision Letter of General Directorate of Taxation No. 78/PJ.41/1990) (Munti and Annisah, 2005 : 30).

\section{Curfews}

Another kind of restriction put by shari a-based bylaws is in relation to women's freedom of movement, such as the regulation on the prevention of sexual immorality enacted in Tangerang, Indramayu, Mataram, West Sumatra, and Gorontalo. These restrictions share a similar common stipulation that anyone whose acts could give rise to suspicions that $s /$ he is a prostitute is prohibited from being on public roads and other public places. It further bans women from traveling alone or being outside of the home without being accompanied by a relative between $10 \mathrm{pm} / 12 \mathrm{am}$ and $04.00 \mathrm{am}$, except where they have a justifiable reason. It can be clearly seen from Gorontalo Province Regional Bylaw No. 10/2003 on Prevention of Sexual Immorality, article 6 (1) "Women are prohibited from traveling alone or being outside of the home without being accompanied by a relative between $12.00 \mathrm{am}$ and $04.00 \mathrm{am}$ except where they have a justifiable reason."

There have been some incidents where innocent women became the victims of the implementation of such regulation such as those occurred in Aceh (International Crisis Group, 2006), West Java (Suara 
Rahima, 2001:34), and Tangerang (The New York Times, "Women Caught", The Age, "Moral Crusaders). Women who suffer most from such restriction are those who have to work at night to support their families. While these bylaws prohibit women to go outside and work at night, they do not describe how to compensate the loss of income of these women because of this restrictive stipulation.

Such a stipulation, to some extent, is influenced by a literal interpretation of a Hadith of the Prophet Muhammad stating that "No woman shall make journey covering the distance of a day and night except accompanies by a male relative (Mahram)" (al-Bukhari and Muslim, $2003:$.95). In a similar vein, another tradition narrates that a man asked the Prophet with regards to his plan to take part in an expedition while his wife also planned a travel for pilgrimage. The Prophet instructed the man to accompany his wife for the pilgrimage and abandon his expedition (al-Bukhari and Muslim, 2003 : 571). However this perspective has been countered by progressive Muslim scholars who argue that the illat (legal reason) of this prohibition, the risk of women's physical and moral safety during travel which became the main concern during the Prophet time, is not applicable in this contemporary situation because nowadays women can travel in a relatively safer situation, thanks to the advancement of science and technology (Baderin, : 95-96).

\section{Women's Dress Codes}

In almost every region implementing shari a, provisions on dress codes have been translated as obligation to wear jilbab (veil) to Muslim women. In addition to jilbab raids on women who do not cover their heads, there are also sweepings targeting on women who wear tight jeans and mini skirts or similar types of clothing (Bowen, 2003, 183184). According to women activists in Aceh, the law has put more burdens on women because they have to spend more times thinking of what to wear before they go out home being afraid of the punishment that they might receive if they don't dress properly (Kompas, 2006).

Such an obligation on veil is influenced by literal interpretation on (Q.S. 33: 53). However, al-'Ashmawy argues that, this verses is directed to the Prophets' wives and it refers to a curtain that had to hang between the male community of the faithful and the Prophet's wives instead of referring to a veiling of the face or a head-covering. A similar verse, (Q.S. 
24: 31), according to him, is intended to modify an ancient Arab custom of covering the head with a scarf or veil but baring the breasts. Thus, the verse called on the faithful women and girls to cover their breast and not to leave them bare as was the custom of the time. Another verse, (Q.S. 33: 59), calls on the faithful women and girls to wear traditional Arabian dress, jallabiyah, without clearly referring to a veil covering the face or head. Al-Ashmawy further contends that based on its historical context, the verse was revealed to differentiate between decent women and slavery harems. As at present time there are no slavery harems, so, he contends, the verse no longer applies. Al- 'Ashmawy also applies a similar method in reading the Prophetic tradition on veil. He generally argues that these verses and tradition have temporary application to the time of the Prophet rather than permanent one because of their specific historical context. Therefore he points out that these texts generally recommend women and girls to dress decently but do not insist women and girls of the twentieth century wear veil. Wearing veil, according to him, must be on voluntary basis not on force or even intimidation using the pretext that it is a command from God or the Prophet (al-'Ashmawy, 1998 : 106-108). This point is further strengthened by Othman who argues that the insistence of many conservatism Muslim activists of the veil on women not only deprive the right or freedom of a Muslim woman to choose for herself but also undermine the moral autonomy of the individual and reduces the personal Muslim females' self-determination (Othman, 2002 : 342). It gains more significance in Indonesian case, as in some regions, women who resist such regulations are sometimes being branded un-Islamic (Noerdin, $2006: 185$ ).

\section{Segregation of Women in Public Spaces}

The practice of discriminative treatment is also found in shari'a regulation regarding the male-female segregation in public spaces. For example, Tasikmalaya Regional Head's Letter No. 556.3/SE/03/ Sos/2001 recommends owners or managers or visitors or patrons of swimming pools in Tasikmalaya Regency to arrange the pools and visiting schedule, as well as working shift schedules, so that men and women are not present at the pools within the same time. Such segregation can be also found in conservative Muslim groups' gatherings and Islamic traditional boarding schools. 
A practice of segregation is often based on a conservative sharia interpretation on the doctrine of ikhtilatkhalwat (which forbids mingling/proximity between men and women), where women are secluded from the sphere of men and are only allowed to have contact with males in the presence of their husbands or of mahram, close male relatives whom they are not allowed to marry. According to this perspective, the public sphere is the authority of men. Even if women take part in public sphere in order to help the productive activities of their husband, they are allowed to do so only from behind a partition. Such a perspective, in fact, reinforces a hegemonic masculinity, a gender relation that legitimizes patriarchy, granting men a dominant position while putting women in subordinate position (Hasan, 2006).

This is in contrast with Muslim women during the Prophet time where they enjoyed the rights to enter into the councils of the Muslim umma, speak freely with the Prophet, dispute with men, fight for their welfare and be involved in the management of military and political affairs (Mernissi, 1991: viii).

However, this situation was set back when Muslim societies brought back into feudalism by the Abbasid dynasty. Women were relegated into private sphere through the custom of harem. At the same time, sharia was codified and gates for ijtihad were closed because sharia was considered fully and exhaustively elaborated at that time. Since then, there has been hardly any significant renewal in the basic structure and methodology of sharia. Thus, sharia has continued to reflect the social, political, and economic conditions of 8-10 C when it was codified and fails to respond to the development and realities of modern Muslim states and societies. Therefore patriarchal readings of the Islamic texts as legacy from the period of codification have continued to the present time, "producing a face of Islam which is oppressive to, rather than liberating, women.” (Munir, “. 5-6).

\section{The Banning of Prostitution}

Under the program of eradication of amoral behavior, almost every region implementing sharia has issued sharia-based bylaws banning prostitution. Some bylaws even define prostitutes as exclusively to women such as Indramayu Regency Regional Level II Regulation No.7/1999 (f) on Prostitution that stipulates "Prostitution is an act where a woman 
offers herself for sexual relations with someone of the opposite sex and accepts payment in the form of money as well as in other forms".

Furthermore, in some regions the regulations give power not only to the police but also to the vigilant groups of society to support the enforcement. Such regulations have not only victimized women but also strengthen the culture of violence against women. Raids by arrestment, harassment, assault, and humiliation in public view are often conducted against women alleged to violate the regulation. Even worse, violent campaigns against brothels and women in sex industry have been accompanied by violent raids to nightclubs, discothèques, and hotels. The impact of such culture of violence, according to Chandrakirana and Chuzaifah, goes beyond the public political sphere because it has intruded into the private homes of women and girls, as reflected in domestic violence and other violence against women (Kemala Chandrakirana and Yuniyanti Chuzaifah, Ibid., p. 12).

According to Musda Mulia, there have been some illogical legal rationales behind such regulations. First, the regulations have focused only on women while the perpetrators of amoral behaviors also include men and the "sex industry" behind it. Second, the regulations have introduced unnecessary precautions by stipulating curfews for women. Third, the aim of eradicating prostitution and other immoral conducts has taken a wrong approach. Prostitution is indeed a social problem whose root, such as economic factors and structural injustice, must be addressed in order to eradicate it (Siti Musdah Mulia, 2002,p.129-133). Thus, these regulations reflect not only the gender bias of shari'a-based bylaws but also "an easy task" approach taken by such formalization of sharia in solving social problems.

\section{The Rise of Islamic Conservatism and Lack of Gender Perspective in Decentralization Policy}

The severe economic-political crisis that hit Indonesia has in fact given opportunities for conservative Muslim groups to breed and gain support among Muslims. The structural poverty and inequality as well as the systematic pattern of bad governance make these conservative groups appealing (Chandrakirana and i Chuzaifah, "The Battle Over a 'New' Indonesia", p. 6-7). Their disappointment of the modern secular state turns them to offer another option: government by religion. 
Therefore, they actively propagate their agenda to return to "Islam" either by the establishment of Islamic state or the implementation of sharia. Their proposal to reinsert the seven words of the Jakarta Charter into the amendment of the 1945 Constitution had been rejected by the majority of MPR (People Consultative Assembly) members in Indonesian constitutional amendments (1999-2002) based on the basis that Indonesia is a not an Islamic state. However, such refusal does not stop the pursuance of their agenda. Being failed at the national level, the conservative Muslim groups shift their strategy by taking advantage of decentralization policy to demand for sharia implementation in predominantly Muslim regions on the basis of the local particularity and the collective rights of majority (Riddell: 2005,p.166).

However, like conservative Muslim groups in other Muslim countries, their agenda to Islamisize society targets firstly and foremost women-women's rights and status in the family and society-and women's body. Othman argues that the control of women, in terms of their social roles, movements, and sexuality, forms the core of the Islamic conservative groups' perspective on gender roles and relations in the 'pristine Islamic society and state' which they seek to establish (Norani Othman, 2006,p.341). Mulia observes a similar pattern among Islamic regimes implementing sharia where they embark on their political program by firstly restricting women. She perceives this as a political shortcut to gain legitimacy because creating a symbol of Islam such as regulating dress codes and other restrictive measures against women is more easily attainable than establishing legitimacy through social and economic development to improve the welfare of the people (Siti Musdah Mulia, 2001,p.17).

Hence, the dissolution of the authoritarian regime and the new era of Indonesian democratization does not necessarily mean that the promotion of human rights, especially women' rights, can proceed smoothly. After the state is not repressive anymore, some groups in the society emerge and pose new challenges for the promotion of human rights. One of such challenges comes from conservative Muslim groups. The tendency to be authoritarian and totalitarian that had been in the state seems to transmit to these groups. There at least two similarities between the New Order regime and Islamic conservatism in which democratic principles are negated by both regimes, thus, both tend to 
limit human rights and democracy in Indonesia (Malden, MA: Polity Press, 1999), pp. 34-35).

First, both the New Order regime and Muslim conservative groups negate the principle of the limited state and a separation of between the public and private sphere. The authoritarian nature of the New Order regime was not only in its hegemonic regime ideology that suppressed any potential forces undermining its power but also in its effort to control all aspects of its people's life. The regime not only totally controlled the public sphere, i.e. socio-political domain, but also the private sphere by standardizing individual morality. The former is reflected in its effort to make Pancasila (the Five Principles) as the sole ideology for all social and political organizations and suppress any differences by repressive measures while the latter is reflected in its creation of discourses on "comprehensive Indonesian humankind", "Indonesia family", "Indonesian children and teenagers", etc. In terms of women life, it created a "state ibuism" ideology (Suryakusuma defines, 1996), pp. 92-119). Like the New Order regime, Muslim conservative groups also intend to not only fuse religion and state but also control both public and private spheres of the society based on their understanding of religious norms. It attempts to subjugate individual autonomy and hegemonize the society under a particular moral norm. In terms of women, the shariatisation pursued by these conservative Muslim groups also attempts to regulate women's private and public life.

Second, both the New Order regime and Muslim conservative groups negate the principle of anti-paternalism of democracy. This principle is based on the epistemological premise that there is no final truth about what is good for society, and that the only criterion for the public good is what the people, freely organized, will choose, not what some expert or prophet decrees on the basis of superior knowledge. The New Order regime created its own political-social discourses to be yardsticks for all Indonesian people and anyone who opposed them will be labeled as subversives. Similarly Muslim conservative groups claim their interpretation of sharia as an absolute truth and attempt to impose it to all Muslims. Anyone who differs from such understandings will be labeled as non-Muslims. This raises concerns among progressive Muslims who believe in the freedom of thinking in Islam as the saying of the Prophet Muhammad: "The differences of opinion among the 
learned within my community are [a sign of] God's grace." Yusuf alQaradawi, for example, also states:

My worst fear for the Islamic Movement is that it opposes the free thinkers among its children and closes the door to renewal and ijtihad, confining itself to only one type of thinking that does not accept any other viewpoints.... The end result will be for the Movement to lose the creative minds among its ranks and eventually fall prey to stagnation." (al-Qaradawi, 1998 : 17).

In pursuing their agenda, these groups usually form a committee to prepare for sharia implementation in each region. Then they seek support from local elites and local governments (Imparsial, Unification and Totalitarianism, p. 17). Political interests seem to motivate local elites and governments to support this sharia implementation. For example, in Cianjur, sharia implementation is used as a tool for political campaign by one of candidates for district head so that he won the election and is elected as the district head, but then he implements sharia through merely religious symbolism (Ibid., p. 13-14). The collaboration of these three groups is perceived as a factor contributing to the issuance of sharia regional bylaws despite the fact that such bylaws have problems not only in their legal standing, as religion in fact remains under the jurisdiction of central government, but also in their legal substance, as they violate the following higher laws: 1) CEDAW (Convention of the Elimination Discrimination Against Women's Right) which is ratified in Law No 7/1984; 2)International Convention on Civil and Politic Rights (ICCPR) which is ratified in Law No 12/2005; 3)Law No 39/1999 on Human Rights; and 4) International Convention on Economic, Social, Cultural Rights (ICESCR) which is ratified in Law No 11/2005. (Jurnal Perempuan Online, http://www.asienhaus.de/ public/archiv/PaperPERDASHARIA.pdf, September 2007 : 7).

These legal problems are further complicated by the lack of women's participation in the formulation of sharia based bylaws. This reflects a wider problem of lack of gender perspective in decentralization. There seems to be low commitment for gender equity and equality among local bureaucrats. Legal illiteracy and unawareness of gender issues among the drafters of the sharia-based by laws partly contribute to multi-interpretational and discriminative legal formulation of these bylaws (Dewi Candraningrum, "Perda Sharia" : 10-11). Although there 
has been a strategy to raise gender awareness among local bureaucrats through gender mainstreaming, its implementation is still facing many obstacles. The pressing matters of economic recovery, communal violence, corruption, and regional revolt has forced local government to prioritize these issues and put gender matters still in periphery (Edriana Noerdin, "Customary Institution" : 185).

The gender bias of decentralization is not only reflected in the local government where men remains dominant but also in the society level where NGOs and other organs of civil society tend to lack of interest to include women in their efforts to facilitate citizens' participation in implementing regional autonomy. Take for example, the Regional Regulation No. 5/2000 of the Special Region of Jakarta that necessitates a member of a village council (BPD) to be the head of the family while the national Marriage Law explicitly define a man as the head of the family, thus, women will be excluded in BPD under this regulation (Noerdin, ,2002: 185). Women's active participation in BPD is in fact urgent to democratize the revitalization of customary institutions; otherwise, such revitalization will simply reinforce the patriarchal values of these customary institutions that further undermine women's rights and interests.

Both the society and the state systems of decentralization are still dominated by men thus women's needs and interests are still marginalized. Although there are also some regional bylaws that support women's rights such as the East Java Regulation No. 9/2005 on the protection of women and children as victims of violence, the Sido Urip Village regulation No. 1/2005 on the protection of victims of violence, the Sumbawa District Regulation No. 11/2003 on the protection of migrant women workers, the number is still relatively few compared to regional bylaws that discriminate against women. Even an effort to request a judicial review for these discriminatory bylaws is facing a challenge. For example, in April 2006, the Supreme Court refused a judicial review on the Tangerang Municipality Regulation No. 8/2005 on Anti-Prostitution on the basis that its drafting procedures have met legal and political requirements, thus, a judicial review on its legal substance is not needed anymore (Komnas Perempuan, http:// www.komnasperempuan.or.id/public/Implementation 1_editted ceda1w.pdf,1 September 2007, p. 3. Hence, women are still vulnerable to threats from both the society and the state. 


\section{Conclusions and Recommendations}

Decentralization that should have opened up opportunities for women to promote their rights has not so far necessarily guaranteed such promotion. Democratization in Indonesia in general and decentralization in particular have not been complemented by the civility of the people to sustain and promote democracy. This is reflected in the case of sharia regional legislation using the pretext of majority rule while democracy itself is essentially based on political pluralism that necessitates equality, non-discrimination, and individual freedom as well as the respect for others' rights. Discrimination against women in these sharia based-bylaws reflects the prevalence of patriarchal system not only in local government but also in the society. Women not only are under-represented in local government and legislative but also suffer from the revitalization of customary institutions laden with patriarchal values. Women tend to be excluded in the decision making and political process, thus, policies dealing with women are still gender insensitive and bias. As a response to the challenge posed by Muslim conservative groups with regards to their agenda for sharia implementation, there is an urgent need for religious reform among Indonesian Muslims in Indonesian democratization era in two forms: first, the reposition of Islam as a system of moral and ethic for Indonesian Muslim within the framework of Indonesian nation-state. In this sense, Islam as a religion with sacral dimension must be separated from politics as mundane affairs. The separation of religion from politics is intended to protect religion so that it is not politicized to serve any political goals and interests (Hefner, 2001: 491).

This is based on historical evidence along the course of Islam which have shown that Islam tended to be employed as a legitimacy by political elites to legalize policies that are in essence contradictive with the substance of Islamic values. In the modern Muslim states, Islam is often used as a political tool by political parties to gain more votes in general elections. Second, religious reform through the reinterpretation of sharia to transform it from restrictive dogmas into a liberating force that can empower Muslim society, especially Muslim women, to achieve social justice in a democratic society.

With regard to the problem of gender bias in decentralization, in addition to advocating the revision of Regional Autonomy Law No. 22/1999 to have a gender perspective, national mechanism of 
gender mainstreaming needs to strengthen networking among gender empowerment agencies at local levels. Women's organizations and civil society need to work together to ensure national gender equity programs are seriously implemented at local level. Promoting women's participation and representation in both local government and community is urgently needed to ensure decentralization not only deals with balancing power between central and local government but also balancing power between men and women.

\section{References}

\section{Books \& Journals}

Abidin, Adi, "1 1 st Indonesia Rapid Decentralizations Appriasal (IRDA) Synopsis of Findings", Conference Paper, Center for Institutional Reform and the Informal Sector (IRIS), University of Maryland at College Park: USA, 2002.

al- Ashmawy, Muhammad Sa id, Against Islamic Extremism, Florida: University Press of Florida, 1998.

al-Qaradawi, Yusuf, Priorities of the Islamic Movement in the Coming Phase, (Cairo: Dar al-Nashr for Egyptian Universities, 1992 in Charles Kurzman (ed.), Liberal Islam: A Sourcebook. New York \& Oxford: Oxford University Press, 1998.

An-Na 'im, Abdullahi Ahmed, "Human Rights in the Muslim World: SocioPolitical Conditions and Scriptural Imperatives A Preliminary Inquiry." Harvard Human Rights Journal, vol. 3, 1990.

Anne, Phillips, "Feminism and the Attractions of the Local", in Desmond King and Gerry Stoker (eds.), Rethinking Local Democracy, London: MacMillan, 1996.

Baderin, Mashood A, International Human Rights, 95-96.

Byrne, Bridget and Julie Koch Laier, "National Machineries for Women in Development: Experiences, Lessons, and Strategies for Institutionalizing Gender in Development, Policy, and Planning", Bridge Report, No. 36,.

Bowen, John R., Islam, Law, and Equality in Indonesia: An Anthropology of Public Reasoning. Cambridge: Cambridge University Press, 2003.

Chandrakirana, Kemala and Yuniati Chuzaifah, "The Battle Over a 'New' Indonesia", 6-7.

Fish, M. Steven, "Islam and Authoritarianism", World Politics, vol. 55, No. 1, 2002, 25-30.

Halford, Susan, "Feminist Change in a Patriarchal Organization: The Experience of Men's Initiatives in Local Government and Implications for Feminist Perspectives on State Institutions", in Mike Savage and Anne Witz (eds.), Gender and Bureaucracy. London: Blackwell, 1992. 
Hasan, Noorhaidi, Laskar Jihad: Islam, Militancy, and the Quest for Identity in PostNew Order Indonesia. Ithaca, New York: Cornell Southeast Asia Program Publications, 2006.

International Crisis Group, "Islamic Law and Criminal Justice in Aceh", Asia Report, no. 117, July 2006.

Maucaulay, Fiona, "Localities of Power: Gender, Parties, and Democracy", in Haleh Afsar (ed), Women and Empowerment: Illustrations from the Third World. London: Macmillan, 1998.

Mayer, Ann Elizabeth. Islam and Human Rights: Tradition and Politics, London: Pinter Publishers, 1991.

Mernissi, Fatimah, "Feminity as Subversion: Reflections on the Muslim concept of Nushuz", in Fatima Mernissi (ed.), Women's Rebellion and Islamic Memory. London: Zed Books, 1996

Mernissi, Fatima, Women and Islam: An Historical and Theological Inquiry, trans. by Mary Jo Lakeland. Oxford: Basil Blackwell, 1991.

Munti, Ratna Batara and Hindun Annisah, The Women's Status in Islamic Law in Indonesia. Jakarta: LBH-APIK, 2005.

Mulia, Siti Musdah, "There Must Be No Compulsion for Jilbab", in Luthfi Assyaukani (ed), The Liberal Face of Islam in Indonesia, (Jakarta: Jaringan Islam Liberal, 2002), p. 129-133.

Mulia, Siti Musdah Swara Rahima, No. 2, 1, August 2001, p. 17, cited in Edriana Noerdin, "Customary Institutions", p. 184.

Noerdin, Edriana, "Customary Institutions, Syariah Law and the Marginalization of Indonesian Women", in Kathryn Robinson and Sharon Bessell (eds.), Women in Indonesia Gender, Equity, and Development. Singapore: ISEAS, 2002.

Othman, Norani "Muslim Women and the Challenge of Islamic Fundamentalism/ Extremism: An Overview of Southeast Asian Muslim Women's Struggle for Human Rights and Gender Equality", Women's Studies International Forum, 29, 2006, p. 341.

Riddell, Peter G., "Islamization, Creeping Shari'a, and Varied Responses in Indonesia”, in Paul Marshall (ed.), Radical Islam's Rules: The Worldwide Spread of Extreme Sharia Law, Lanham: Rowman and Littlefield Publishers, 2005.

Robin, Bush, "Regional "shari'ah Legislation: Anomaly or Symptom?", paper presented at Indonesian Update 2007 on Expressing Islam: Religious Life and Politics, Canberra: The Australian National University, 8 September 2007.

Robert W. Hefner, "Public Islam and the Problem of Democratization", Sociology of Religion, vol.62, No. 4, 2001, 491.

Stowasser, Barbara, "Gender Issues and Contemporary Quran Interpretation”, in Yvonne Yazbeck Haddad and John L. Esposito, Islam, Gender, and Social Change. New York \& Oxford: Oxford University Press, 1998. 
Sharabi, Hisham, Neo Patriarchy: A Theory of Distorted Change in Arab Society, (New York: Oxford University Press, 1988), pp. 6-8, 32-39, as cited from M. Steven Fish, "Islam”, p. 30.

White, Sally, "Sharia as Local Politics", in Virginia Hooker and Greg Fealy (eds.), Voices of Islam in Southeast Asia: A Contemporary Sourcebook, Singapore: ISEAS, 2006.

Weiss, Anita, "Implications of the Islamization Program for Women", in Anita Weiss (ed.), See for example Ann Elizabeth Mayer, Islam and Human Rights: Tradition and Politics. London: Pinter Publishers, 1991.

\section{Report \& News Paper}

The Age, "Moral Crusaders Focus on Female", 11 March 2006, The New York Times,

Kompas, "Women, Perda, and Domestication”, 4 March 2006.

"Women Caught in More Radical Islam", 28 June 2006; SBS Dateline Archive, "Indonesia - Pornography and Politics", June 28 2006,

Independent Report of Indonesian National Committee for the Elimination of All Forms of Violence Against Women, "Important Matters with Regards to the Implementation of CEDAW Convention in Indonesia", Komnas Perempuan, 19 July 2007, http://www.komnasperempuan.or.id/public/Implementation 1_editted ceda-1w.pdf, [retrieved at 1 September 2007], p. 3.

Suara, Rahima, No. 2, 1 August 2001: 34.

Nur Hidayah, Faculty of Sharia \& Law, UIN Syarif Hidayatulah Jakarta.

Email: nurhidayah@uinjkt.ac.id 